\title{
Viewpoint
}

Open Access

\section{Africa's COVID-19 story: cheap innovation technology and climate protective effect to her rescue?}

\author{
*Adesokan, A., and MacLean, M. \\ PreciseMed 272 Bath Street, Glasgow, G2 4JR Scotland \\ *Correspondence to: dapoadesokan@gmail.com; Ade@precisemed.co.uk
}

\begin{abstract}
:
As the COVID-19 pandemic sweeps the globe, causing tens of thousands of deaths in most Western countries with economies round the world in turmoil, Africa has so far been largely spared the kind of impact that has thrown the United States, South America and Europe into crisis. Most African countries remain seriously unprepared to handle the pandemic of the nature the Western world is dealing with; Africa, from Mali to Ethiopia to Libya and down to South Africa, have insufficient ventilators or intensive care beds to cope with COVID-19 should it strike with ferocity as it is doing in the Western world. As COVID-19 reaches the shores of Africa, despite poor health facilities, poor living conditions and inadequate availability of clean water across the continent, Africans are still putting up a fight taking COVID-19 head on with use of cheap technology, and help from the continent's protective climate. However, Africa cannot afford to be complacent. African countries must continue to adopt strict social distancing measures, educate their people on the importance of intake of regular vitamin $D$, good exercising habit, good sleep pattern, adequate hand hygiene measures, as well as strictly enforcing the "test, trace and isolate" model to the letter for the continent to take on the fight head on and wage a proper war against COVID-19.
\end{abstract}

Keywords: SARS-COV-2; COVID-19; innovation; technology; climate; Africa

Received Aug 25, 2020; Revised Oct 10, 2020; Accepted Oct 14, 2020

Copyright 2021 AJCEM Open Access. This article is licensed and distributed under the terms of the Creative Commons Attrition 4.0 International License $<$ a rel="license" href="http://creativecommons.org/licenses/by/4.0/", which permits unrestricted use, distribution and reproduction in any medium, provided credit is given to the original author(s) and the source. Editor-in-Chief: Prof. S. S. Taiwo

\section{L'histoire du COVID-19 en Afrique: une technologie d'innovation bon marché et un effet protecteur du climat à sa rescousse?}

\author{
*Adesokan, A., et MacLean, M. \\ PreciseMed 272 Bath Street, Glasgow, G2 4JR Écosse \\ *Correspondance à: dapoadesokan@gmail.com; Ade@precisemed.co.uk
}

\begin{abstract}
Abstrait:
Alors que la pandémie du COVID-19 balaie le globe, causant des dizaines de milliers de morts dans la plupart des pays occidentaux avec des économies du monde entier en crise, l'Afrique a jusqu'à présent été largement épargnée par le type d'impact qui a jeté les États-Unis, l'Amérique du Sud et l'Europe en crise. La plupart des pays africains ne sont pas vraiment préparés à faire face à la pandémie de la nature à laquelle le monde occidental est confronté; L'Afrique, du Mali à l'Éthiopie en passant par la Libye et jusqu'en Afrique du Sud, ne dispose pas de ventilateurs ou de lits de soins intensifs insuffisants pour faire face au COVID-19 s'il frappe avec férocité comme dans le monde occidental. Alors que le COVID-19 atteint les rives de l'Afrique, malgré des installations de santé médiocres, des conditions de vie médiocres et une disponibilité insuffisante d'eau potable à travers le continent, les Africains continuent de se battre en prenant le COVID-19 de front avec l'utilisation d'une technologie bon marché et l'aide de le climat protecteur du continent. Cependant, l'Afrique ne peut pas se permettre d'être complaisante. Les pays africains doivent continuer à adopter des mesures de distanciation sociale strictes, éduquer leur population sur l'importance de l'apport régulier de vitamine D, de bonnes habitudes d'exercice, un bon sommeil, des mesures d'hygiène des mains adéquates, ainsi que l'application stricte du «test, traçage et isolement». modèle à la lettre pour que le continent se batte de front et mène une véritable guerre contre le COVID-19.
\end{abstract}

Mots clés: SRAS-COV-2; COVID-19; innovation; La technologie; climat; Afrique 


\section{Introduction:}

Coronavirus is a large family of respiratory viruses; pathogenic examples are the severe acute respiratory syndrome-corona virus (SARS-COV), the Middle East respiratory syndrome-coronavirus (MERS-COV), SARSCOV2, and other coronaviruses that cause common cold. They are found in animal hosts such as camels, cattle, bats and other animals. Coronaviruses have caused two large-scale pandemics in the past two decades; SARS and MERS $(1,2)$. The current pandemic, COVID-19 caused by SARS-COV-2, was first reported in Wuhan China on December 31st, 2019 and soon became a global disease of immense significance, due to global travel. It is transmitted mainly through inhalation of respiratory droplets, but other means of transmission include contact with infected persons and surfaces, as well as inhalation of SARS-COV-2 infected aerosols.

Since World War II, the world has not witnessed anything of such magnitude as COVID-19. The pandemic so far has struck and stretched the heart of the western world beyond many of its individual nations' health system capacities. Therefore, it is fair for the rest of world to fear for Africa, the continent home to 1.2 billion people, without sufficient ventilators, personal protective equipment (PPE), testing capacity, and intensive care unit beds. Most African countries remain seriously unprepared to handle the pandemic of the nature the western world is dealing with. Compared to the United States which has 34 beds for every 100,000 persons (3), African countries have insufficient ventilators or intensive care beds to cope with COVID-19 should it strike with the ferocity observed in the Western World.

In most parts of Africa, people live in overcrowded conditions making social distancing, a critical prevention COVID-19 strategy, a practical impossibility. Millions of Africans live without access to clean running water, which makes frequent hand washing also a difficult ask (4). Most African countries were already or suffering from the overburdening effect of tuberculosis, HIV/ AIDS, and noncommunicable diseases, and infectious diseases such as cholera, measles, and malaria. Adding COVID-19 to the mix could draw the analogy of the straw that broke the camel's back. While under pressure, intensive care units in Europe and the US were complaining of lack of adequate ventilators and PPEs in the early days of the COVID-19 outbreak, most African countries could only rely on hand hygiene, social distancing measures, and isolation centres to fight the deadly scourge of COVID-19.

The COVID-19 pattern globally, is that $80 \%$ of those infected will not require hospita- lization, that is either because they end up as asymptomatic carriers or go on to be mildly symptomatic, and about $20 \%$ could become significantly ill with COVID-19. Most of the latter will need oxygen treatment, and about a third of this hospitalized population will result in critical cases requiring continuous positive airway pressure (CPAP) or mechanical ventilation (5). Without such advanced care for this critically ill group of people, death by complications of acute respiratory distress syndrome (ARDS) and widespread microthrombosis, which is the hallmark of critical COVID-19, is all but inevitable.

In Western countries, hospital availability of oxygen to treat patients is taken for granted. In Africa, few countries have hospitals where oxygen is available, and where they do exist, oxygen concentrators demand stable electricity supplies which are not always available. In an analytical study of the critical care capacity across 54 African countries (6), there was an average of 3.10 ICU beds and 0.97 ventilators per 100,000 people. The average number of ICU beds per 100,000 people ranged from 0.53 in low-income countries to 8.59 in upper-middle income countries, the highest being 33.07 in Seychelles, the only high-income country included in the analysis (6). The average number of ventilators per 100,000 people ranged from 0.14 in lowincome countries to 2.49 in upper-middleincome countries. The average number of ICU beds was lowest in West Africa with only 1.10 ICU bed per 100,000 people, and the average number of ventilators was lowest in East Africa with only 0.23 ventilators per 100,000 people. There was an average of 2.42 total (physician and non-physician) anaesthesia providers per 100,000 people ranging from 1.24 and 0.66 in low-income countries and the Middle African region respectively, to 6.91 and 6.64 per 100,000 people in the upper-middle-income countries and the North Africa region, respecttively.

As the COVID-19 pandemic sweeps the globe, causing tens of thousands of deaths in Western countries and throwing economies round the world into turmoil, Africa has so far been largely spared the kind of impact that has thrown the United States, South America and Europe into crisis. As of mid-April, there were about 14,000 confirmed cases on the African continent, as compared with 160,000 in Italy and more than 560,000 in the United States $(7,8)$. Despite the slow arrival of the pandemic in Africa, the numbers are slowly rising, implying the 1.2 billion people living in Africa are at tremendous risk.

It is fair to assume that one of the reasons African countries are reporting low rates of infection is due to its limited testing capacity. As at April 9, 2020, Africa CDC reported that Nigeria with a population of 200 
million people had only conducted 6,000 tests and Ethiopia with a population of about 100 million people had conducted about 5,000 tests (9). While this is true for some countries, the likes of Senegal, Ghana, South Africa, Mauritius, and others have ramped up their testing capability. However, African countries continue to record low mortality rates of COVID-19 which can be gauged from level of hospitalizations and number of deaths with history of respiratory symptoms, should the actual tests for COVID-19 not be available. Therefore, this viewpoint is an attempt to hypothesize the reasons for the low COVID-19 mortality rates in Africa.

\section{Cheap COVID-19 technology}

Confronting epidemics is not new to Africans, and their previous challenging, but successful experiences may prove to be pivotal in the fight against COVID-19. For generations, Africans have been responding to infectious diseases, both governments and communities realise the need for rapid, proactive measures to save lives in the face of scarce advanced health facilities and resources. Over the years, Africans have devised their own traditional treatment modalities and technologies, through simple and low-cost ways of fighting different infectious diseases that have come their way in the past. Moreover, a substantial number of countries in Africa have benefited from previous global initiatives to strengthen health systems to address HIV, malaria, tuberculosis, and Ebola (10). In addition, the Africa CDC has accelerated its work to enhance diagnostic and surveillance capacity on the continent since the start of the outbreak of the COVID-19, and is putting together an effort to distribute one million test kits across Africa (9).

Senegal is the role model of the continent, where local experts are led by Amadou Sall, the Director of WHO Collaborating centre for Arboviruses and viral haemorrhagic fever at the Insitut Pastuer de Dakar. His team is leading the way in curbing the COVID-19 pandemic by providing testing for all its citizens. The West African nation is engaging in the "test, trace and isolate" model to good effect, building on its experience in fighting HIV/AIDS and Ebola. The Insitut Pasteur is creating a 3D printed $\$ 60$ ventilator and $\$ 1$ testing kit so cost-effective and of high quality that the British Biotech company, Mologic, is engaging in collaboration with Insitut Pasteur 's Biotech Dia Tropix to make 10 minutes test kits (11). The institute plans to make 2 to 4 million diagnostic test kits available soon in the fight against COVID-19 pandemic. Senegal has put resources in place to share its other strategies with other countries on the continent.
Immediately after the news of the outbreak was confirmed in January, Rwanda, another shining light on the continent for the last 20 years, after putting the horrors of genocide behind it, trained about 500 health workers to deal with a potential national epidemic, putting strict social distancing guidance with a focused and result-oriented leadership from President Paul Kagame. Rwanda has deployed five state-of-the-art humanoid robots to aid in fight against COVID19. Health Ministry officials said that the robots could deliver food and medication and screen the temperatures of 50 to 150 people per minute. The Rwandans gave their COVID19 robots local names; Mwiza, Ikizere, Akazuba, Urumuri and Ngabo.

Mauritius, the tiny African holiday island resort, enforced an early lockdown and rolled out mass testing capable of testing $10 \%$ of its population with 100,000 tests carried out within two weeks of the outbreak. Its healthcare facilities, which boast of 3.4 hospital beds per 1,000 people (12) competes favourably with the giants of the Western world. Its health workers are well prepared should the pandemic take a turn for the worse.

In Nigeria, the advent of COVID-19 has bred innovation in terms of development of ventilators by the likes of the National Defence Academy (NDA) and several Universities, as well as factories making PPEs in form of face shields, face masks and gowns. Drivethrough COVID-19 testing and mobile disinfectant units are also being developed and deployed around the country. People who are suspected of showing symptoms can have their symptoms registered online and are screened to ascertain whether they qualify for a test; and can then drive through a testing centre and receive their results electronically.

In Kenya, at the large regional hospitals, teams of health workers have set up tents to provide information on COVID-19, take temperatures readings and log the travel histories of the local residents before they enter the hospitals. The deployment of these cheap and effective technologies across Africa is a welcome development and should be further supported by individual governments in the fight against the pandemic.

\section{Africa's climate protective effect}

The Spanish flu of 1918 affected 500 million people and killed about 50 million worldwide ( $\sim 10 \%$ mortality rate), including an estimated 675,000 people in the United States $(13,14)$. Italy's COVID-19 mortality rate as at $4^{\text {th }}$ of April 2020 stood at $17 \%$ with 15,362 deaths out of 88,274 recorded infections (15), making Italy the nation with the highest death rate worldwide, far worse death rate than the Spanish flu's over 100 years ago. 
Africa, home to nearly 1.2 billion people, continues to puzzle scientists why it has the least infection rates globally. Majority of cases in West Africa are index cases brought in by travellers from Europe, US, and South East Asia. South Africa has 1,000 cases with 9 deaths as at $4^{\text {th }}$ of April, 2020; and Nigeria has 214 cases and 4 deaths (16), which implies that as at $4^{\text {th }}$ of April, 2020, Africa has hardly had more than 100 deaths, neither has Africa recorded more than 100,000 cases (16). All these may indicate there could be a reason for this negligible mortality rate compared to the rest of the world. The hypothesis here is that to be highly transmissible, SARS-COV-2 virus requires temperatures between $2-13^{\circ} \mathrm{C}$ for infectivity and transmission judging by the finding from the Chinese study (17). The Chinese study found that in areas of average temperature of $18^{\circ} \mathrm{C}$, infection rates are less than $5 \%$. Also, areas in China with hot and humid weather had slower waves of transmission of COVID-19. Most regions of Africa have temperatures averaging between $25^{\circ} \mathrm{C}$ $40^{\circ} \mathrm{C}$ as at April 2020, therefore the theory is that hot, humid climate slows down the community spread of SARS-COV-2, hence the low infection and mortality rates recorded in Africa thus far.

Humidity is postulated to affect the transmission of Influenza outbreak in a similar manner to COVID-19. Small mucus droplets spread in the air in hot, humid conditions, and loses it infectivity because the particles lose their structural integrity in such conditions. The fact that respiratory droplets become less virulent in humid and tropical weather, might account for the low mortality rates seen in Africa. To buttress this low virulence, low mortality climate theory, hotter and humid areas of China like Beijing and Shanghai had lower infection rates, and lower mortality rates compared to more temperate regions like Wuhan Hubei province (17). The Chinese study revealed that there were in total 24,139 confirmed cases in China and 26 overseas countries, of which, 16,480 cases $(68.01 \%)$ were from Hubei Province (17). The number of cumulative total confirmed cases $(\operatorname{lgN})$ rose as the average temperature went up to a peak of $8.72^{\circ} \mathrm{C}$ and then slowly declined. The apexes of the minimum and maximum temperatures were $6.70^{\circ} \mathrm{C}$ and $12.42^{\circ} \mathrm{C}$ respectively, and the curves shared similar shapes. Under the circumstance of lower temperature, every $1^{\circ} \mathrm{C}$ decrease in average, minimum and maximum temperatures led to an increase of the cumulative number of cases by $0.83,0.82$ and 0.83 respectively.

In the single-factor model of the higher-temperature group, every $1^{\circ} \mathrm{C}$ increase in the minimum temperature led to a decrease of the cumulative number of cases by 0.86 (17). The downside to this theory is the fact that Africa like the rest of the world has 2 seasons; summer and winter. This however uniquely occurs at the same time in different parts of the continent simultaneously. As of mid-April 2020, there were about 14,000 confirmed cases on the African continent, compared to figures by $16^{\text {th }}$ of August 2020 , where Africa's COVID-19 cases had passed the 1.1 million mark (18). Despite the slow arrival of COVID-19, the numbers have risen steadily when the figures obtained in April are compared to that of August, implying the 1.2 billion people living in Africa are at tremendous risk. The reason for this is likely due to the fact that, when COVID-19 emerged, most of Africa in the tropics had their dry, hot season ongoing, compared to April to October when the raining, colder and wetter season starts and encouraging more COVID-19 infections owing to plummeting temperature and humidity as earlier hypothesised.

In Nigeria for example, the dry season typically runs from November to March, with temperatures that average about $37^{\circ} \mathrm{C}$ during the day, while the wet season typically runs from April to October. During this time, the southern part of the country alone can receive more than 150 inches of rainfall, which invariably cause drop in temperature. Thus wetter, colder climate encourages spread of respiratory viruses like SARS-COV-2 and Influenza as earlier highlighted. In contrast, on the same continent, the climate of South Africa is uniquely different from most parts of Africa because it lies between two oceans; Atlantic and Indian, in $22^{\circ} \mathrm{S}$ and $35^{\circ} \mathrm{S}$ latitude in the Southern Hemisphere. This confers upon the country a subtropical climate with lower temperatures even in the "summer" dry season compared to the rest of Africa with tropical climate all year round.

Interestingly, to buttress this different climate conferring different COVID-19 rates theory, as of August 16, 2020 according to Johns Hopkins University data (18), worldwide proven infection rate stood at $21,593,607$ with 773,685 deaths and 13,594,900 recoveries. During the same period, South Africa had recorded a total of 587,345 infections with 11,839 deaths compared to Nigeria's 49,068 infections and 975 deaths. The reason for this very significant disparity in number of infections and deaths is likely due to the fact that while COVID-19 started during Nigeria's dry, hot season, which is in contrast to South Africa, where it started during winter in its subtropical climate. Thus, South Africa's colder climate like the rest of temperate world as highlighted earlier in this viewpoint could be argued as facilitating more infections and 
invariably higher death rates compared to Nigeria's or the rest of Africa with tropical climate all year round.

\section{Discussion}

As the COVID-19 pandemic sweeps across the globe, causing tens of thousands of deaths in most Western countries and massive economic disruption, Africa has so far been largely being spared the kind of impact that has thrown the United States, and Europe into crisis. When it reached the shores of Africa, despite poor health facilities, poor living conditions and unavailability of clean water across the continent, Africans' still put up a fight to take COVID-19 head on with use of cheap technology, with further help from the continent's protective climate. The likes of Senegal's' flagship \$1 COVID-19 test kit and $\$ 60$ ventilator are initiatives that would make the rest of the world marvel.

Scientists across Africa have also proposed the cross immunities theory, arguing that malaria and other infectious diseases endemicity in Africa might have protective effect on the low COVID-19 infection and mortality rates observed in Africa. However, the fact that Africans living in the western world who grew up in Africa exposed to these infectious diseases died from COVID-19 related causes in substantial number in the western world adds little credence to this theory.

Going forward in the face of limited resources to fight this pandemic, if Africa must wage a formidable and viable war against this "invisible enemy" COVID-19, it must adhere to excellent use of public health tools. It must also have an effective Test, Trace \& Isolate model. Social distancing and hand hygiene education must become the norm and the continent must invest in local cheap PPE and diagnostics technology. Lockdowns should continue to be enforced where necessary and there should be an acute awareness of the language of the COVID-19 virus; "COVID-19 does not move, People move it, we stop moving, the virus stop moving", It is that simple.

However, all said and done, Africa cannot afford to rest on its laurels. African countries must educate its people on the importance of regular intake of Vitamin D, good exercising habit, good sleep pattern, adequate hand hygiene measures, as well as strictly enforcing the "test, trace and isolate" model to the letter. The good gesture and measures like that of President Donald Trump planning who donated to Nigeria 200 ventilators and South Africa 1000 ventilators, is highly commendable.

In the face of possible catastrophic consequences of COVID-19 should it strike
Africa as it has struck the West, the United Nation Economic Commission for Africa (UNE CA) reported a worst-case scenario for Africa projecting that between 300,000 and 3.3 million people could die from COVID-19 in Africa (19). Sadly, the practice of medical tourism by African leaders and their families even for minor ailments, and their highly corrupt practices may have finally caught up with Africa with the advent of this pandemic. African leaders have misplaced their priorities over the years, by not putting to good use the vast human and natural resources at its disposal to provide adequate health care and infrastructures for Africans in Africa. Nigeria has made more than $\$ 400$ billion from crude oil sales alone since 1960 . South Africa's mining wealth is worth around $\$ 2.5$ trillion, while Democratic Republic of Congo's mineral reserves is worth $\$ 24$ trillion, to mention a few. Sadly, the whole continent cannot boast of up to 2000 working ventilators worth $\$ 15,000$ a piece ( $\$ 30$ million in total) to fight the scourge of COVID-19 pandemic.

On the bright side, COVID-19 might be the much-needed impetus African leaders need to wake up and get their priorities right by using the opportunity to develop our decaying and moribund health systems. Therefore, should future pandemics emerge, Africa would be in good stead to take on the fight head on and wage a proper war.

\section{About the principal author}

Dr Adedapo Adesokan is a Physician Pharmacologist who runs a University of Strathclyde, Scotland supported start-up, PreciseMed, a pharmaceutical R\&D company set up in 2017 for developing novel medical devices and pharmaceutical products for unmet clinical needs.

\section{References}

1. Drosten, C., Günther, S., Preiser, G., et al. Identification of a novel coronavirus in patients with severe acute respiratory syndrome. $\mathrm{N}$ Engl J Med. 2003; 348: 1967-1976

2. Zaki, A. M., van Boheemen, S., Bestebroer, T. M., Osterhaus, A. D. M. E., and Fouchier, R. A. M. Isolation of a novel coronavirus from a man with pneumonia in Saudi Arabia. N Engl J Med. 2012; 367: $1814-1820$

3. Wallace, D. J., Angus, D. C., Seymour, C. W., Barnato, A. E., and Kahn, J. M. Critical care bed growth in the United States: a comparison of regional and national trends. Am J Respir Crit Care Med. 2015; 191: 410-416.

4. World Health Organization. Key facts from JMP $2015 \quad$ report. 2015. https://www.who.int/water_sanitation_health/ publications/JMP-2015-keyfacts-en-rev.pdf

5. Huang, C., Wang, $Y, L i, X$, et al. Clinical features of patients infected with 2019 novel coronavirus in Wuhan, China. Lancet. 2020; 395: 497-506.

6. Craig J., Kalanxhi E., Hauck S., Estimates of Critical Care Capacity in 54 African Countries. The Center For Disease Dynamics, Economics \& Policy (CDDEP) Report, May 14, 2020 
7. Center for Systems Science and Engineering (CSSE) at Johns Hopkins University. COVID-19 dashboard. https://coronavirus.jhu.edu/map.html 8. Africa Centres for Disease Control and Prevention. COVID-19 dashboard. https://africacdc.org/covid-19/

9. Report Africa Centre for Disease Control and Prevention (Africa CDC). Updated April 9th 2020. https://africacdc.org/covid-19/

10. Mwisongo, A., and Nabyonga-Orem, J. Global health initiatives in Africa - governance, priorities, harmonisation and alignment. BMC HIth Serv Res. 2016; 16 (Suppl 4): 212.

11. Aljazeera Report Senegal:10 minutes Coronavirus test kits may be on its way for $\$ 1$. Updated March 29th 2020. https://www.aljazeera.com/news/2020/03/sene gal-10-minute-coronavirus-test-1-200327053 901231.html

12. Report. Trading economics.com/Mauritius/ hospital-beds-per-100-people-wb-data.html. May2020.https://tradingeconomics.com/mauriti us/hospital-beds-per-1-000-people-wbdata.html

13. Johnson, $\mathrm{P}$, and Mueller, Updating the accounts: global mortality of the 1918-1920 "Spanish" influenza pandemic. Bull Hist Med. 2002; 76 (1): 105-115.
14. Jester, B., Uyeki, T. M., Jernigan, D. B., and Tumpey, T. M. Historical and clinical aspects of the $1918 \mathrm{H} 1 \mathrm{~N} 1$ pandemic in the United States. Virology. 2019; 527: 32-37.

15. Zampano G., COVID-19: Italy reports 681 new deaths, rate slows. Anadolou Agency Report 4th of April, 2020

16. WHO Update 4th of April Situation update worldwide, as of 4 April 2020 European Centre for Disease Prevention and Control. https://www.afro.who.int/news/update-covid19-04-april-2020

17. Wang, M., Jiang, A., Gong, L., et al., Temperature Significantly Change COVID-19 Transmission in 429 cities. medRxiv preprint. doi: https://doi.org/10.1101/2020.02.22.20025791

18. COVID-19 Dashboard by Centre for Systems Science and Engineering at John Hopkins University report. Updated 16th of August 2020. https://coronavirus.jhu.edu/map.html

19. Report: COVID-19 in Africa: Protecting lives and economies. United Nations Economic Commission for Africa report. Updated April 2020. https://www.un.org/africarenewal/news/corona virus/eca-report-covid-19-africa-protectinglives-and-economies 